\title{
8
}
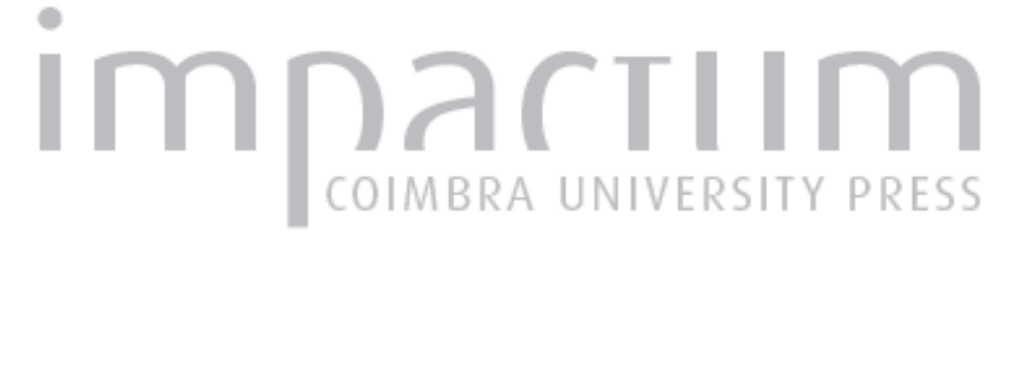

\section{Introdução a uma filosofia do conhecimento}

\section{Autor(es): $\quad$ Reis, José}

Publicado por: Faculdade de Letras da Universidade de Coimbra, Instituto de Estudos \section{Filosóficos}

URL

persistente:

DOI: $\quad$ DOI:http://dx.doi.org/10.14195/0872-0851_34_1

Accessed : $\quad$ 26-Apr-2023 14:28:27

A navegação consulta e descarregamento dos títulos inseridos nas Bibliotecas Digitais UC Digitalis, UC Pombalina e UC Impactum, pressupõem a aceitação plena e sem reservas dos Termos e Condições de Uso destas Bibliotecas Digitais, disponíveis em https://digitalis.uc.pt/pt-pt/termos.

Conforme exposto nos referidos Termos e Condições de Uso, o descarregamento de títulos de acesso restrito requer uma licença válida de autorização devendo o utilizador aceder ao(s) documento(s) a partir de um endereço de IP da instituição detentora da supramencionada licença.

Ao utilizador é apenas permitido o descarregamento para uso pessoal, pelo que o emprego do(s) título(s) descarregado(s) para outro fim, designadamente comercial, carece de autorização do respetivo autor ou editor da obra.

Na medida em que todas as obras da UC Digitalis se encontram protegidas pelo Código do Direito de Autor e Direitos Conexos e demais legislação aplicável, toda a cópia, parcial ou total, deste documento, nos casos em que é legalmente admitida, deverá conter ou fazer-se acompanhar por este aviso.

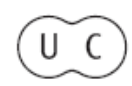




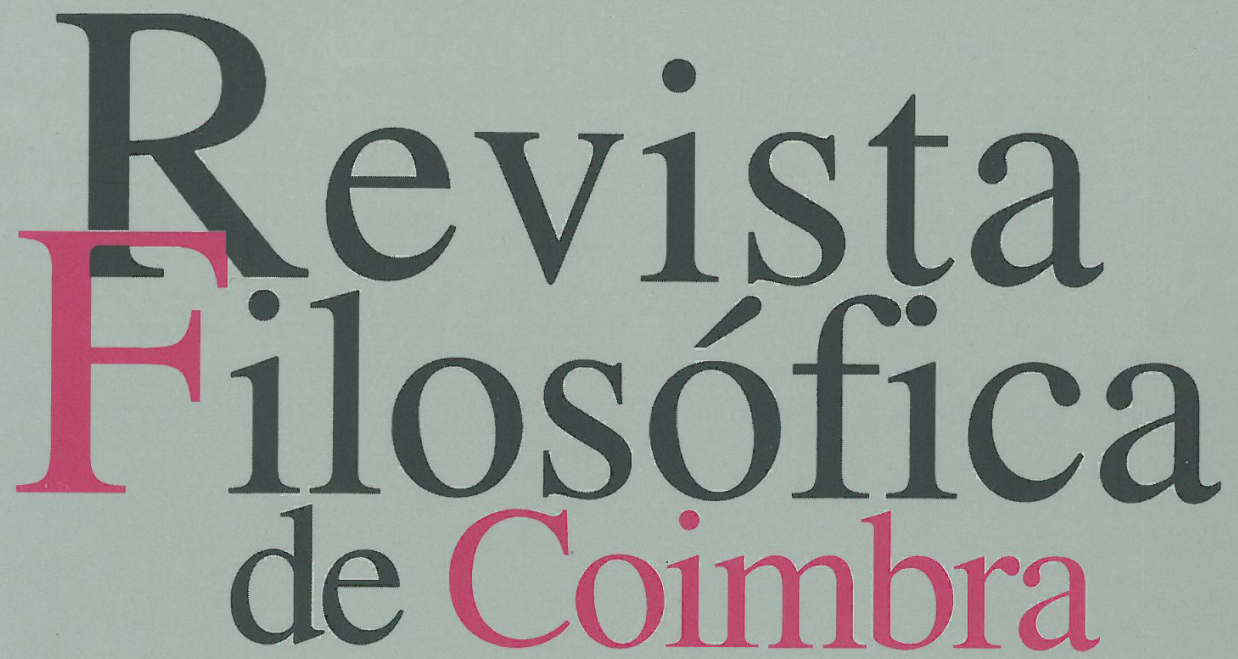

vol.17 | n.34 | 2008

José Reis

Manuel Moreira da Silva Helder Gomes

Filipe P. S. M. Menezes Edmundo Balsemão Maria João Silveirinha Luís António Umbelino Cláudio Alexandre S. Carvalho Armindo dos Santos Ana Isabel Boura Regina Queiroz Dulce Morgado Neves 


\title{
INTRODUÇÃO A UMA FILOSOFIA DO CONHECIMENTO
}

\author{
JOSÉ REIS
}

(Instituto de Estudos Filosóficos - Faculdade de Letras - Universidade de Coimbra)

1. O acto comum como a essência do conhecimento, em Aristóteles e na Filosofia Moderna

Ao iniciar a introdução a uma Filosofia do Conhecimento, a primeira coisa necessária, a meu ver, é evocar o «acto comum» de Aristóteles. Conhecer é: juntar a consciência às coisas por conscienciar, dando como resultado as coisas conscienciadas; ou, para citarmos as suas próprias palavras, «o acto do sensível e o acto do sentido são um só e mesmo acto, mas a sua quididade não é a mesma». São um só e mesmo acto, porque se juntam, constituindo um apenas; mas juntam-se preservando cada um a sua essência, de modo que geram justamente uma con-junção ou composto. Se houvesse dúvidas quanto ao sentido do que o Estagirita quer dizer, logo o seu próprio exemplo as tiraria. «Tomo o exemplo», escreve na verdade, «do som em acto e do ouvido em acto. Pode acontecer que aquele que possui o ouvido não ouça e que o que tem o som não ressoe sempre. Mas quando passa a acto aquele que tem o poder de ouvir, e que ressoa aquilo que tem o poder de ressoar, então produzem-se simultaneamente o ouvido em acto e o som em acto, aos quais podemos chamar respectivamente a audição e a ressonância» ${ }^{1}$. Poderá decerto haver o som sozinho - bem como as cores sem a vista ou os sabores sem o gosto como logo adiante referirá contra «os primeiros fisiólogos» ${ }^{2}$. Mas, nessa altura, não haverá conhecimento. Para que este exista, é necessário juntar ao acto do objecto, isto é, àquilo que ele é, o acto do sujeito ou acto de consciência, gerando-se em conjunto o objecto conscienciado.

\footnotetext{
${ }^{1}$ ARISTÓTELES, De an. III, 2, 425 b 25-426 a 2. Cf. 15-17.

2 Ibid. 19-22.
} 
E não se diga que, depois de Descartes, Kant e Hegel, para só referir estes, voltar a Aristóteles é um anacronismo. Porque, sem dúvida, com Descartes as coisas para o acto comum deixaram de se ver, com Kant elas passaram a alterar-se completamente ao serem recebidas pelo sujeito, e com Hegel chegou-se mesmo à conclusão de que, se o conhecimento é uma tal alteração, então o absoluto (o que há para conhecer), como ele dirá no início da Introdução à Fenomenologia do Espírito, não é pássaro que caia na armadilha. Mas em nenhum dos casos o conhecimento propriamente dito deixou de ser a tomada de consciência das coisas e, por conseguinte, o acto comum. Em Descartes, com efeito, tudo o que acontece é que as coisas se deixaram de ver para além das ideias, mas vêem-se ainda estas: por falta de raio de acção do sujeito, não é possível o acto comum com as coisas, mas é-o com as ideias. Aliás, é por esta razão que, não se vendo as coisas, estas são postas em dúvida, mas, vendo-se as ideias, elas não o são. Tal como continua o acto comum nos fenómenos kantianos. De resto Kant julga que os próprios númenos, enquanto são o fundamento dos fenómenos, ainda de algum modo se vêem nestes; pelo que só ficam mesmo as efectivas determinações numénicas por ver. E em Hegel é certo que nada propriamente se vê, antes toda a solução do problema do conhecimento parece ser a de que o objecto é produzido pelo sujeito; mas, e justamente, é produzido para poder ser visto, portanto para poder haver o acto comum, tal como o anterior já havia sido recusado por não se ver, por não se poder realizar com ele o acto comum; pois era porque, sendo exterior ao sujeito, ele tinha de ser recebido por este - e nessa recepção se alterava radicalmente - que tal objecto não se podia conhecer: dizia-se que o conhecíamos, mas ao fim e ao cabo o que conhecíamos eram os nossos modos activo e passivo e nada dele; ao ser agora produzido pelo sujeito, o novo objecto não só não se tem de receber, e nessa recepção alterar-se, como é mesmo à partida da própria natureza do sujeito; pode por isso, ao menos supostamente, conhecer-se.

É assim de facto um dado que, com Descartes, Kant e Hegel, as anteriores coisas propriamente ditas se deixaram de ver. Mas passaram a ver-se outras, mudando o acto comum apenas de objecto, para além de que até o não-conhecimento das primeiras continua a testemunhar, por deficiência, esse mesmo acto comum. O que na verdade aconteceu foi que este acto comum se pôs desde sempre sobre a representação. E, como esta última acabou por levar a problemas que pela sua própria natureza pareciam mais graves e anteriores, foi para aí que voltámos o olhar e o acto comum praticamente desapareceu de vista. Ele, como acabamos de ver, lá continua como o conhecimento propriamente dito; mas os problemas que se impuseram passaram a ser os outros (a transcendência 
das coisas relativamente às ideias em Descartes, a recepção-alteração em Kant, e em Hegel a produção do objecto por parte do sujeito) de tal modo que dele já nem se fala. Daí, na verdade, a aparência da sua ausência, nomeadamente nos tempos modernos. Mas daí tanto mais a necessidade de, ao iniciar-se uma Filosofia do Conhecimento, pôr em relevo o referido acto comum. Porque o facto é que «transcendência ou imanência», «recepção ou produção» não são «conhecimento». Podem facilitá-lo ou dificultá-lo, consoante os casos; mas conhecimento - como a simples existência da sua palavra para além das outras o diz - é tomar consciência de uma coisa por conscienciar, é pôr o problema como Aristóteles o fez.

\section{O conhecimento como representação em Aristóteles, e objectivo do artigo}

É certo que no mesmo Aristóteles o conhecimento também se põe em termos de representação. Põe-se mesmo tanto em tais termos que por exemplo um O. Hamelin - como é bem conhecido - o caracteriza como um paralelismo (como um duplo no sujeito do real exterior), sendo neste caso o problema o de saber como se alcança tal duplo: se por transição do objecto exterior para o interior da alma - em termos realistas portanto - ou pela produção do objecto interior por parte do sujeito - à maneira idealista. Mas para além deste paralelismo, para além da representação, não é menos certo que ele põe expressamente o problema em termos de acto comum. E como, pela sua própria natureza, o problema essencial do conhecimento é afinal o deste acto comum, é para ele que antes de mais temos de chamar a atenção. Foi o que fizemos.

Só que tal obviamente não chega. A representação, no seu duplo género, quo e quod, autodestrói-se. E, se assim é, nós temos em primeiro lugar de saber - já que ela é uma ilusão - como ela afinal surgiu, como surgiu a ideia da duplicação do objecto no sujeito. Só depois devemos proceder à sua referida destruição. O que faz com que, uma vez liberto o conhecimento da representação, fiquemos apenas com o acto comum. Pois bem, é então chegado o momento de o analisar, a ele próprio. Porque a verdade é que também ele se autodestrói, pela razão de que a consciência por um lado e o objecto sem consciência por outro não são coisa alguma. Desaparece deste modo a representação e desaparece o acto comum. Quer isto dizer que tudo desaparece? Não. Há, num exemplo que avançaremos, um terceiro acto de consciência, que contém imanente a transcendência, desta maneira se achando o que verdadeiramente há. 


\section{Origem do primeiro género da representação}

O próprio Aristóteles, pois, põe o acto comum sobre o conhecimento como representação. Ora porquê isto? Se estamos a ver a coisa lá fora e é exactamente o que vemos, até Descartes - porque não dizemos que há simplesmente o som lá onde ele se dá e, partindo de nós mas chegando lá, a consciência dele? É porque, sendo nós antes de mais o nosso corpo, o qual se situa aquém do som que lhe é exterior, é então em nós que acontece a consciência desse som e não nele? Mas isso é supor o que justamente está em jogo. Seja o que for que a consciência se venha a revelar, se ainda só há o som lá mesmo onde ele se situa, é lá e só lá que ela toma consciência dele. Podemos decerto, se somos antes de tudo o nosso corpo, tomar primeiro consciência deste; mas também saímos e tomamos consciência dos objectos lá onde eles se situam, porque nesta análise metódica nada mais ainda há. Porque se supôs um duplo do som em nós, através do qual, então sim, tomamos consciência do som lá fora?

Julgo que tudo começou com a existência da memória. Foi ela que primeiro se pôs em termos de representação, generalizando-se depois tais termos à percepção. Nós, com efeito, também temos o poder de evocar as coisas na sua ausência. Ora, se as coisas presentes se vêem porque estão presentes, como se explica que se vejam ainda as ausentes? Como quer que depois se venha a articular a explicação, ao menos uma coisa é certa desde o início: é que, se na percepção estamos voltados para as coisas, pois que são elas que, presentes, determinam aquilo que vemos, na memória é a partir de nós - nós que somos antes de mais o nosso corpo $^{3}$ - que elas se põem, e que portanto se vêem. Mas, é claro, não há ainda nem de longe a ideia de que somos nós que as produzimos. E, por outro lado, só as podemos mesmo recordar a partir do momento da sua percepção. Nestas condições, a explicação que se viria a articular foi a de que elas de algum modo em nós entram nessa altura e, conservandose, nos permitem depois a memória. É o que, como bem se conhece, diz Agostinho a propósito do tempo. Se o passado já não existe, como o podemos ainda evocar? «As coisas», responde, «ao passar pelos sentidos, deixaram as suas imagens, como vestígios, gravadas no espírito» ${ }^{4}$. E já antes Aristóteles havia equacionado todo o problema. Aquando da sensação, escreve, imprime-se na alma uma imagem - uma espécie de pintura, ou uma espécie de sinal gravado como o do sinete na cera - cuja

3 O nosso corpo no meio de outros corpos presentes que não são as coisas memoradas: é este o quadro.

${ }^{4}$ SAnto AGOSTINHO, Conf. XI, 23. 
posse constitui a memória ${ }^{5}$. Sem esta imagem, com efeito, porque a coisa está ausente, nada haveria para ver ${ }^{6}$. Contudo, esta mediação traz uma dificuldade: tal imagem, que se tem de ver, é uma coisa presente; ora, se se vê e está presente, isso é uma sensação: como se pode transformar na memória da coisa ausente? ${ }^{7}$ A solução está em que, quando utilizamos a imagem como meio para a memória, e não portanto como objecto, não é a ela mesma que vemos mas à coisa ausente, à qual ela simplesmente nos leva ${ }^{8}$. Voltaremos a isto mais adiante. O que aqui importa notar é que, se na percepção, dada a presença das coisas, tudo o que se passa é que olhamos para fora, na memória, ainda olhamos decerto para fora, para as próprias coisas lá onde elas se situam no espaço e no tempo, mas a partir do nosso corpo, mediante um duplo delas que nele se conserva.

Eis, como dizíamos, a memória posta em termos de representação. Contudo não ficámos por aí. Rapidamente tais termos se generalizaram à própria percepção, graças à importância prática dessa mesma memória no conjunto da nossa experiência. É que conhecer é, do ponto de vista da nossa acção, adquirir (como ainda hoje se diz) e carregar connosco os conhecimentos necessários para as diversas situações. Quer estejamos simplesmente a recordar o passado (connosco próprios ou contando-o aos outros) ou a evocar pormenores seus em ordem às nossas acções imediatas, a memória está constantemente na nossa experiência. Queiramo-lo ou não, somos pensadores. Mesmo os homens de acção o são, enquanto a cada momento projectam o que vão fazer. Ora, se isto é assim, a memória com o seu duplo em nós passou a ser tão importante e tão habitual que também e insensivelmente a percepção se passou a interpretar nos mesmos moldes. É certo que agora, estando presentes as coisas, as vemos imediatamente e não é preciso nenhum duplo. Mas o facto é esse: dado o relevo da memória no nosso conhecimento prático, habituámo-nos de tal modo a chegar às coisas ausentes a partir do seu duplo em nós que também e sem dar pela diferença assim o passámos a fazer em relação às próprias coisas presentes. De resto, uma vez articulada a explicação da memória, passámos a saber que é aquando da percepção que em nós entra um duplo das coisas: ora, se já nessa altura há um duplo, é já através dele que, daí em diante, assumidamente se dá a percepção. E por outro lado não é menos certo que, embora digamos que é a partir do duplo das coisas que as recordamos, tal duplo nunca se vê, antes só se vêem mesmo as coisas recordadas; pelo que, acontecendo exactamente o mesmo na

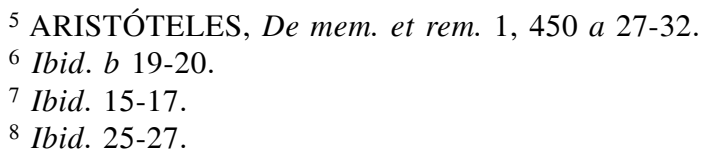

6 Ibid. $b$ 19-20.

${ }^{7}$ Ibid. $15-17$.

8 Ibid. 25-27. 
percepção, não há nenhuma diferença entre um caso e outro a dificultar a passagem: sendo os duplos em ambos os casos meramente supostos, nada impede que, se o hábito o impõe, se faça mais uma suposição. Eis também a percepção posta em termos de representação. E ei-la mesmo sobretudo a ela em tais termos, já que é ao seu nível que se dá o conhecimento «em pessoa» e, por isso, original. Eis o acto comum, precisamente ao nível da percepção, não como a simples conjunção da consciência e das coisas lá fora, mas como essa mesma conjunção através de um duplo das coisas em nós.

\section{Origem do segundo género}

Notemos contudo que ainda tomamos, justamente, consciência das coisas lá fora. O conhecimento já se põe em termos de representação, mas de representação, para retomarmos a terminologia de J. Maritain, ela mesma tomada da tradição tomista, em termos quo e não quod ${ }^{9}$ : o duplo é aquilo através do qual se vê a respectiva coisa, não $o$ que se vê. Este último tipo de representação só surgirá quando Descartes, sobre o primeiro, duvidar metodicamente das coisas. Sobre o primeiro, porque não são os erros dos sentidos ou as ilusões do sonho que constituem um duplo das coisas, antes apenas lançam mão do já existente, assim o fazendo, isso sim, não só mais visível mas mesmo aquilo que se vê. Os primeiros, com efeito, como o ficámos a saber a partir da distinção husserliana entre os actos que «significam a vazio» e os que «preenchem pela presença em pessoa», não são erros em relação a um ser transcendente que por definição não se vê, mas em relação a uma futura percepção ${ }^{10}$. Uma torre, por exemplo, que de longe nos aparece como redonda, só é erro em relação a uma segunda percepção que, efectuando-se ela de mais perto, no-la dá como quadrada. E ainda, em rigor, não é a primeira percepção que se transforma em erro: de longe o que há é exactamente o redondo, já que não se vêem os pormenores do quadrado; errada é a imaginação que, dela partindo, supõe que a torre continua redonda quando nos

${ }^{9}$ J. MARITAIN, Distinguer pour unir ou Les degrés du savoir, Desclée de Brouwer, Paris, 1946, Annexe I, A propos du concept, pp. 769-819.

${ }^{10}$ Refiro-me naturalmente à capital doutrina husserliana - que desde as Investigações Lógicas atravessa toda a sua obra - da percepção como o absoluto da referência, face a todas as outras modalidades de actos que ainda se referem às coisas mas com maiores ou menores graus de a-vazio. Ver nomeadamente Investigações Lógicas, Sexta Investigação, §§ 14, 21, 26-28, 37 e 45; Ideias-I, §§ 136-138; Meditações Cartesianas, $\S 24$. 
aproximamos. Os erros dos sentidos passam-se assim, em verdade, numa única dimensão, sem duplos do lado de cá e coisas que não se vêem do lado de lá. Mas, bem entendido, isto é assim hoje depois de Husserl, pela volta de toda a história do conhecimento. No imediato, a torre - que é aquilo a que sem mais nos referimos, sem estar determinada como de longe ou de perto ${ }^{11}$ - é ela mesma redonda primeiro e depois quadrada, o que não pode ser. Sendo um facto adquirido que o conhecimento se dá através de um duplo das coisas recebido em nós, a explicação óbvia é que nem sempre tais duplos se revelam fiéis mensageiros. Ou seja, eis justamente o erro em termos de um duplo aquém das coisas, as quais desta maneira se deixam de ver. Repitamos que a torre como redonda é decerto um erro em relação à percepção de que é quadrada. Mas desde que o erro propriamente dito, na explicação imediata que recorre ao duplo, é a diferença que vai dela como redonda a uma realidade que não se conhece, podemos até supor que também ela como quadrada é igualmente um erro em relação a esse transcendente, e temos quer o cepticismo quer Descartes.

Isto em relação aos erros dos sentidos. Para o sonho, passa-se o mesmo. Ele é uma imaginação que, ao acordarmos, se confronta com uma percepção; no exemplo de Descartes, imaginamos que estamos «vestidos ao pé do lume»e, ao acordar, percebemos que estamos «todos nus na cama» ${ }^{12}$. A única diferença, agora, é que essa imaginação não se inscreve num processo de conhecimento, porque o sonho não é uma percepção, e por outro lado, não havendo a dormir a percepção com a qual ele se possa comparar, ele não se sabe uma imaginação. Mas nem por isso, como é óbvio, a deixa de ser, como o simples facto de falarmos nas ilusões do

${ }^{11}$ Só os Epicuristas - com o seu acento na verdade de todas as percepções, e isto porque «dizer que uma sensação é falsa seria dizer que nada pode ser percebido», CÍCERO, Acad. priora, II, $\S 101$ - parecem ter sido levados a tomar as coisas enquanto determinadas pelo modo como nos aparecem. E tanto que os seus adversários os acusarão de «subjectivismo», de reduzirem o real a um conjunto de «impressões imediatas», como diz E. BREHIER, Histoire de la Philosophie, I, PUF, Paris, 1967, p. 299. Contudo é óbvio que não só, para voltarmos ao exemplo, há para eles uma verdadeira torre, a quadrada, cujos pormenores de longe somente não se vêem, como há de cada vez o verdadeiro real para além das percepções através das quais o conhecemos. Aliás, por haver também para eles este real é que verdadeiramente podem ser acusados de um eventual subjectivismo. Quero dizer: em relação a Husserl esta acusação não teria sentido, porque só há mesmo aquela única dimensão, na horizontalidade da qual se passa o erro; não se pode dizer que se perdeu o que positivamente se estabelece como não existindo.

12 R. DESCARTES, Meditações, 1, in Oeuvres philosophiques, ed. F. ALQUIE, Garnier Frères, Paris, 1967, t. II, p. 406. 
sonho o confirma: sendo por definição uma realidade menor que a percepção, é naturalmente ela que ao acordarmos cede o lugar a esta ${ }^{13}$. Deste modo, não há igualmente um plano de cá, a imaginação, e um real transcendente de lá, antes há apenas a relação imaginação-percepção. Mas eis que logo esse real transcendente aparece. Ao supor-se que a própria percepção pode ser um sonho e, portanto, que ela pode ser uma ilusão por não haver o ser a que se refere, este ser é tão transcendente que nem pode haver dele, por definição, mais percepção. Contudo, ele é assim transcendente, notemo-lo, justamente porque se trata de uma percepção: o sonho não pretende conhecer nenhum ser que minimamente lhe seja transcendente, e é só a percepção que, ao supor-se como errada porque uma ilusão, implica não só um duplo mas um duplo como mau mensageiro, o qual é o que se passa a ver na vez da coisa, que assim é remetida para a transcendência. O que significa que, se já não eram os erros dos sentidos que constituíam o duplo das coisas, antes apenas se

${ }^{13}$ Exactamente na linha dos actos que significam «a vazio» e dos que «preenchem pela presença em pessoa», a imaginação visa sempre mais do que tem, visa a percepção, de que só tem parte. Mas no sonho, não havendo esta percepção, ela julga-se o pleno. Por isso o sonho se julga, enquanto decorre, o próprio real. Que no entanto não é, como logo face à percepção o reconhece, em virtude de ser mais pobre. É na verdade por esta razão que ela cede o lugar à percepção (e não se toma esta ao contrário por sonho). Mais pobre, precisemo-lo, estruturalmente. Terminada uma percepção, há agora o nada dela; se do seio deste nada me refiro ainda a ela, posso ter todas as suas determinações, mas já como não presentes, através do nada que ela é agora. À medida que estes momentos de nada se vão acumulando (porque o tempo não pára, com as outras coisas) ela não só continua ausente (não presente, não «em pessoa») como vai perdendo nitidez e mesmo as determinações. Cf. para este ponto o meu estudo O tempo em Sto. Agostinho, in $R F C 14$ (1998) pp. 328-329.

Aparentemente - precisemo-lo ainda - a imaginação não é, na análise já clássica que lhe faz SARTRE (L'imaginaire, Gallimard, Paris, 1940), este visar mais do que tem. Ao contrário mesmo, como ele escreve, na percepção é que «há infinitamente mais que não podemos ver», enquanto na imagem «há uma espécie de pobreza essencial» (pp. 20, 171). Mas isso é porque - para além de que ele interpreta ainda a percepção como o dar-se-nos de um objecto exterior, que pode assim ter sempre mais pormenores - a imaginação de que ele trata é a fictícia, que se esgota na imaginação que é, não a real; embora parta de exemplos reais, como é nomeadamente o caso de «Pedro», não lhe interessa, como uma vez o acaba por dizer explicitamente (pp. 230-232), nem a «memória» nem a «previsão», que são justamente a imaginação real. Não tendo eu Pedro, o que sou ainda capaz de me figurar dele? (p. 238) - é o seu problema. Ora como, quando há Pedro, eu me limito a recebê-lo (o real, exterior, dá-se-me), quando não o há, eu finjoo: caso em que ele não passa exactamente do que eu aí ponho e, já pobre porque finito o conjunto de determinações que aí ponho, é ainda mais essencialmente pobre porque nenhum ser (sempre o exterior) aí está. Na concepção que defendo (e que vai para além 
serviam do já existente, agora o sonho ainda o constitui menos: ele apenas serve para estender a interpretação da percepção como errada definitivamente a todos os $\operatorname{casos}^{14}$.

Tal como - não deixemos de o referir - também não é a tomada de consciência das coisas (ou seja, o acto comum) que constitui o duplo, originando desta feita, pelo lado de cá, a «coisa conscienciada» e, pelo lado de lá, a simples «coisa» que enquanto tal parece ser transcendente. Se em Hume, por exemplo, ao tratar da origem da substância, ou em Kant, no fim da longa nota do Prefácio B, isto é assim, tal é porque já estamos depois de Descartes e, por isso, não só os actos de consciência já são representações (perceptions ou Vorstellungen) mas representações que são aquilo que se vê, não se vendo pois as coisas. Só por isso Hume pode dizer que «a constância das nossas percepções (...) gera a opinião da existência contínua dos corpos, a qual por sua vez gera a sua existência distinta» ${ }^{15}$; e Kant que «a representação de algo permanente na existência

de uma certa ambiguidade ainda presente em Husserl a partir da sua teoria da retenção) as coisas não são assim. Na percepção, não há nada que não se veja: os pormenores que ainda ou já não se vêem, se os penso, são imaginação, não justamente percepção; esta é assim sempre limitada, há de cada vez o que se percepciona, nem mais nem menos, e nenhumas outras determinações, as quais, se não as imagino, então estão pura e simplesmente fora da consciência. E por outro lado o real é esta percepção mesma, não o que, sendo-lhe anterior ou posterior, lhe é exterior. Neste contexto, a imaginação sempre, do ponto de vista do conhecimento que é aqui o nosso, a real (como já dissemos, a memória e a previsão) - só não é o real porque, embora referindo-o, já não o tem «em pessoa»; já só o tem, como também dissemos, através do nada que ele é agora; nada que justamente lhe faz perder a presença, e mesmo progressivamente a nitidez e o número de determinações; é a isto que ela não tem que a imaginação real ainda se refere, mas a vazio. A percepção, ela mesma, resumamo-lo, já é limitada ou finita (embora perfeita na sua presença); a imaginação é ainda uma limitação maior, quanto ao que tem: uma limitação não só na nitidez e número de determinações, mas antes disso em relação à estrutural ausência que a constitui; é esta diferença do que ela não tem que ela visa.

${ }^{14}$ É com efeito neste contexto que Descartes passa dos erros dos sentidos ao sonho. «Mas, ainda que os sentidos - escreve - nos enganem algumas vezes no que toca às coisas pouco sensíveis e muito afastadas, há talvez muitas outras das quais não se pode razoavelmente duvidar», como, por exemplo, tratando-se do nosso corpo. «Contudo (...) sou homem e tenho o costume de dormir e de me representar em sonhos» esse mesmo corpo. Por isso, «suponhamos pois que estamos a dormir e que todas essas particularidades, tais como abrir os olhos, mexer a cabeça, estender as mãos, e outras que tais, são falsas ilusões». O. c. pp. 405-407.

15 D. HUME, A treatise of human nature, ed. SELBY-BIGGE, Clarendon Press, Oxford, 1960 (1888), p. 199. Cf. pp. 214-216. 
não é idêntica à representação permanente, porque esta pode ser muito mutante e variável, como são todas as nossas representações, mesmo as da matéria, e contudo elas reportam-se a algo permanente, que deve pois ser uma coisa distinta de todas as minhas representações e exterior a mim» ${ }^{16}$. Em tais condições, sem dúvida, as coisas situam-se para além das percepções, de tal modo que, mesmo durante o tempo em que as vemos, não são elas mesmas que vemos mas as percepções. Mas, se removemos este duplo dos actos de consciência, eles ficam puros actos de consciência, e as coisas ficam sem nenhuma mediação. Então, enquanto as vemos, é sempre a elas e só a elas que vemos, por mais que sejam consideradas como independentes de serem vistas. Também não é pois o acto comum que constitui o duplo.

Ele nasceu, apenas e como dissemos, para explicar a memória, donde se estendeu à percepção. E foi depois o erro nesta que não só o tornou mais visível mas mesmo o que se vê. Na verdade, a memória cedo nos levou, em virtude da sua importância prática, a interpretar também a percepção à sua imagem e semelhança: como a entrada em nós de um duplo das coisas, através do qual então vemos as coisas lá fora. Só que há às vezes o erro. Neste contexto, o mais natural era interpretá-lo em termos de uma mediação infiel. Eis não nó o duplo mais visível, porque no acto de se libertar da sua funcionalidade, mas ele mesmo o que se vê. É que, no caso do erro, alguma coisa se continua a ver e, na exacta medida da sua infidelidade, é ele mesmo que se vê e não a coisa. - No que podemos chamar a atitude dogmática, que ao fim e ao cabo não dá importância às situações de erro, temos na mesma um duplo através do qual se efectua a percepção; mas ele é extremamente dócil, deixa-se investir totalmente pela função que desempenha e, ainda que presente, não se faz visível. Mas se, como acontece até já no dogmatismo dos Estóicos e dos Epicuristas, já se é minimamente crítico face aos erros que não se podem pura e simplesmente ignorar - pelo que já é necessário estabelecer um critério de verdade ${ }^{17}$-, então nessa medida ele ganha densidade, ele liberta-se da função que desempenha e já aparece. Com os Cépticos, que precisamente chamaram a atenção para essas situações de erro e as estenderam à percepção em geral, passámos a ver exclusivamente o duplo

16 B p. XLI. Itálicos nossos.

17 É com efeito o que já significa a sua preocupação por um critério (kritêrion) da verdadeira percepção. Mas ainda são, até pelas críticas que lhes foram feitas e nós conhecemos, fundamentalmente dogmáticos. Tal como mais dogmático é ainda, porque até sem estas preocupações, Aristóteles e o pensamento medieval que o segue. Cf. para as ditas preocupações em prol de um critério, o que é talvez ainda hoje o melhor resumo desta problemática, em BREHIER, o. c. pp. 267-269 e 298-302. 
e não mais as coisas. - Pelo que, de certo modo, a representação de género quod até já existe antes de Descartes. Mas há uma diferença fundamental. Os Cépticos ficam na dúvida, Descartes não. É para encontrar, como ele diz, um «ponto de Arquimedes» que ele a realiza ${ }^{18}$. Ponto que ele na verdade encontra, e que é a sequência dos duplos ou ideias que eu sou, quando os sou ${ }^{19}$. Eles existem, porque se vêem clara e distintamente, ao contrário das coisas, que não se vêem. Ele não diz decerto, pelo menos com tanta força, que estas não existem por não se verem; tudo o que faz é «supor» ou «persuadir-se» de que não as há ${ }^{20}$ e mais tarde elas voltarão mesmo a ser afirmadas de novo. Mas se o critério para afirmar as ideias é que elas se vêem, o que não se vê por definição não existe. Se elas depois ainda voltam a ser afirmadas, é porque, embora indirectamente, por meio da existência de Deus, ainda se vêem. No imediato, e é essa a atitude decidida de Descartes que o distingue dos cépticos, há os duplos porque se vêem, e o resto logo se verá; no imediato, na exacta medida em que deveras se vêem os duplos, deixaram de se ver as coisas, com as consequências que esse ver ou não-ver acarretam. Eis não só o ver como condição do ser - e por isso inaugurado o mundo moderno, feita a primeira e mais importante revolução copernicana - mas também eis que ficámos fechados, agora sim, nos duplos das coisas.

\section{Legitimidade do método cartesiano e seu desenvolvimento posterior}

É certo que o erro como o duplo infiel que se vem antepor à coisa, que nos haveria de conduzir a este fechamento, só é possível porque se desconhece o que Husserl virá a descobrir: que ele afinal se passa em termos de imaginação-percepção. Mas é esse o facto: desconhecendo-se isso, o erro põe-se imediatamente em tais termos, e bastaria até que ele se desse num único caso para que fosse não só legítimo mas necessário o método cartesiano; pois se, nessa dada percepção, nós já descobrimos que o que vemos não é afinal a coisa mas um duplo infiel dela, nada nos garante que não se passe o mesmo com todas as outras percepções e nós só não o sabemos ainda; se queremos que o nosso conhecimento seja absolutamente certo, temos de supor metodicamente que tudo aquilo que atingimos são duplos das coisas, e a respeito destas só poderemos depois concluir de acordo com as evidências que ainda tivermos. Daí que a dúvida cartesiana não seja apenas, como quer Maritain, o resultado de um engano terminológico, da troca do «conceito», que seria quo, pela «ideia»

\footnotetext{
18 DESCARTES, Meditações, 2, o. c. pp. 414-415.

${ }^{19}$ Ibid. pp. 415-422.

${ }^{20}$ Ibid. p. 415.
} 
que enquanto arquétipo divino é quod ${ }^{21}$; Maritain é, a este propósito e como toda a tradição da chamada philosophia perennis, não-crítico. Se se levam minimamente a sério os erros e se se quer um conhecimento absolutamente certo, é preciso começar metodicamente pelo que se vê e só depois passar, se ainda houver razões para isso, ao que não se vê. É o que fundadamente faz Descartes, e os autores modernos depois dele, agravando de cada vez mais o problema.

Locke, partindo metodicamente das ideias, ainda as toma como representativas de uma realidade exterior; mas não só a sua certeza já é apenas de natureza prática e não uma demonstração à maneira de Descartes, como, sendo impossível ao nosso espírito conceber que as ideias simples possam existir sem serem inerentes a uma substância, esta última não é ao fim e ao cabo um feixe constante de ideias simples, mas um substrato para além delas, que nos permanece desconhecido ${ }^{22}$. Berkeley é mais radical: tendo em primeiro lugar concluído, ao menos para o sentido da vista, que as qualidades primeiras são tão subjectivas como as segundas, tendo intuído depois que as ideias não podem ser representativas porque uma ideia só pode assemelhar-se a outra ideia, e tendo enfim argumentado que a matéria nada é porque não tem qualquer determinação, é levado à anulação do plano das coisas e a ficar só com o das ideias ${ }^{23}$. A radicalidade de Hume é de outro género: tendo posto o problema de saber como, a partir das percepções, se pode ainda constituir a permanência das coisas, numa primeira fase pura e simplesmente não a constitui: é o fenomenismo crítico; mas depois, invocando a imaginação, acaba afinal por a constituir, assim restaurando, mas neste contexto, o

21 J. MARITAIN, o. c. pp. 790-791. Não digo que esta terminologia, que tem confessadamente por parte de Descartes a origem que Maritain lhe atribui, não tenha ajudado o autor da dúvida. Mas só veio trazer mais nitidez ao que já era o essencial do problema; a saber, que o que se vê, na tradição que leva a sério o erro, é o duplo das coisas e não estas, porque elas não se vêem mais e algo se continua a ver. - Que assim é, prova-o a atitude já crítica dos Estóicos e dos Epicuristas e a tradição céptica, que justamente não partem de nenhuma ideia de género quod. Aliás, se fosse como Maritain diz, como se explicaria em contrapartida que as «ideias» se tornassem meios para conhecer as coisas? Elas explicam de facto que os duplos passem a ser «o que se vê»; mas não que isso que se vê seja meio, errado ou não, para conhecer as coisas.

22 J. LOCKE, An essay concerning human understanding, Dover Publications, New York, 1959, liv. II, cap. XXIII.

23 G. BERKELEY, Works, ed. LUCE e JESSOP, Thomas Nelson, London... 1948 ss. Ver nomeadamente, para o primeiro ponto, A new theory of vision, § 41. Para o segundo, The principles of human knowledge, $\S 8$, e Three dialogues, p. 206. Para o terceiro, The principles, $\S \S 16,68,80$, e Dialogues, pp. 187-188 ss. e 222-226. 
plano das coisas para além do das percepções ${ }^{24}$. Compromisso que de uma outra maneira vai continuar em Kant: pois, tomando por um lado as qualidades primeiras como princípios a priori do sujeito para permitir a Matemática, e assumindo por outro a tradição das qualidades segundas como recepção-alteração das primeiras, recepção-alteração que ele eleva mesmo a princípio do conhecimento humano face à espontaneidade-criação do intuitus originarius, ele chega ainda decerto a um conhecimento, mas a um conhecimento que já tem consciência de que nada afinal conhece das coisas originais ${ }^{25}$. O que faz com que Hegel, para só referirmos estes, tire a sua conclusão: se as coisas originais, os númenos, ao passarem pela sensibilidade já se alteram de alto a baixo, e depois ainda se alteram mais porque são sobredeterminadas pelas nossas formas a priori, então elas não são pássaro que caia na armadilha; o conhecimento, se existe, não implica a recepção de um objecto alheio, mas a sua produção por parte do sujeito ${ }^{26}$.

Quer dizer: o conhecimento, a partir de Descartes, transformou-se, anteriormente ao conhecer mesmo, no problema de saber se ainda há as coisas para além das ideias e, neste caso, em saber como lhes aceder; em última análise, conhecê-las deveio produzi-las. E no entanto tal fechamento, na sua origem, nem era mesmo um problema real. Foi o que Husserl nos veio mostrar com a sua descrição dos actos que «visam a vazio»e dos que «preenchem pela presença em pessoa» ${ }^{27}$. Na verdade, só a imaginação é constitutivamente a referência a uma percepção, e esta por sua vez não é mais referência a coisa nenhuma. Atentemos bem na questão. As ideias que verdadeiramente estão em jogo na dúvida

${ }^{24} \mathrm{Cf}$. as referências já feitas na nota 15 .

$25 \mathrm{O}$ primeiro ponto resulta de que o coração da Estética é a «exposição transcendental» do espaço e do tempo. O segundo é visível desde a definição de sensibilidade como «a capacidade de receber representações (receptividade) graças ao modo como somos afectados pelos objectos» (A 19, B 33) até à justificação desse intuitus derivativus face ao originarius: nós, finitos, só podemos receber os objectos (e nessa recepção alterá-los), face ao Ser infinito, para quem conhecer é criar (B 72). E a conclusão, que deriva dos dois pontos anteriores, é assim logo enunciada a partir da I Nota geral sobre a Estética (A 41-46, B 59-63).

26 É o projecto logo indicado, como dissemos, no início da Introdução à Fenomenologia do Espírito.

27 Como escreve A. DE WAELHENS (art. Husserl in Les Grands Philosophes, direcção de MERLEAU-PONTY, Lucien Mazenod, Paris, p. 326): «Os critérios de Husserl põem fim a uma dificuldade insolúvel na perspectiva clássica que, depois de tudo confundir sob o nome de representação, procura então distinguir as representações umas das outras usando apenas diferenças extrínsecas ou graduais, tais como a clareza, a força, a constrangência da representação». - As referências são feitas acima, na nota 10. 
cartesiana são percepções. Ora a imaginação visa sem dúvida mais do que tem e, por isso, ela é constitutivamente a referência à percepção. Mas esta por sua vez não visa mais coisa alguma. E se visasse, importa notá-lo, esta coisa para além dela é que passaria a ser uma imaginação: ainda decerto com a plenitude da percepção, mas já isso mesmo longe, não-acessível, e nessa exacta medida menos. Não só, pois, se já temos tudo, não nos referimos a mais coisa nenhuma, como, se nos referíssemos, esta última é que seria menos, não mais. De resto, se fosse até o mesmo, que sentido faria dizer que o real é isso que não se vê, e não isto mesmo que aí está? Só o hábito crítico de interpretar a percepção como a percepção de uma coisa transcendente que nunca aparece - ele mesmo vindo do erro interpretado à luz do duplo recebido em nós para explicar a memória nos pode ter levado a pensar que o que percebemos é uma ideia ou duplo nosso do verdadeiro real. Se nos atemos, e é o que Husserl faz com a sua pura descrição fenomenológica, aos dados imediatos, o plano do real é já e só o da própria percepção, não há nenhum ser transcendente que fique para além dela.

6. Para além da destruição husserliana da representação de género quod, é preciso também destruir a de género quo

Simplesmente Husserl não identifica a origem deste ser transcendente: não diz que ele é o que, em virtude da anteposição do duplo infiel, fica para além deste duplo. E, pior, sendo o duplo, antes de infiel, aquilo que se supõe como mediador em todo o conhecimento, ele aceita-o e usa-o a este nível. O que quer dizer que ele destrói, sim, a representação de género quod, mas deixa intacta a quo, que está na sua origem. Ora a verdade é que também esta última não é possível. Em primeiro lugar, porque não há na nossa experiência nenhum duplo pelo caminho: há as coisas lá onde elas existem e é tudo: não temos de tomar consciência de um duplo das coisas primeiro, e só depois passar para elas. E em segundo lugar vimos decerto como Aristóteles já refere que, quando se trata de tomarmos o duplo como meio para chegarmos à respectiva coisa, nós não o vemos «por si mesmo» (kath' hautò), mas como a «imagem de uma outra coisa» (állou phántasma) ${ }^{28}$; ou, nas palavras que Maritain cita de Caietano, «o movimento para a imagem enquanto ela é imagem e o movimento para a coisa são um só e mesmo movimento» ${ }^{29}$. Só que, o que quer isto dizer? Sem dúvida, que não paramos na imagem; nesse caso,

${ }^{28}$ De mem. et rem. 1, 450 b 25-27.

29 J. MARITAIN, o. c. p. 781. 
tomá-la-íamos a ela mesma como objecto e não seria mais meio para a coisa. Mas então, e é o problema, como vamos na imagem para a coisa? A primeira alternativa é que, se chegamos à coisa, é porque a imagem é transparente. De outro modo - sendo ela meio e por isso o primeiro elemento a ser visto, e por outro lado já não se tratando de, mesmo subrepticiamente, passar dela para a coisa - vê-la-íamos a ela, e já não veríamos nunca a coisa. Só que, se ela é transparente, não vemos nada dela, e não é meio. Para ser meio, e é a segunda alternativa, temos de a ver a ela. Mas, se a vemos, e quer isto suceda pelo caminho ou sobre a coisa, não vemos mais a coisa, e não é igualmente meio. É, esta segunda alternativa, o que afinal sucede no erro. E também o que sucede na relação husserliana noese-noema, só que desta vez assumindo-se não mais como erro mas como a verdadeira solução do problema do conhecimento: o objecto não é mais o ser que já aí está da atitude natural, mas precisamente o produto da passagem da intencionalidade pela hylê da vivência, o chegar a ele através do seu duplo em nós ${ }^{30}$. Certamente que Husserl não quer explicitamente isto; nesse caso não haveria, em rigor, mais mediação nenhuma: haveria o noema, que seria a própria hylê projectada como objecto, e mais nada; ele pensa tanto a hylê como mediadora, e portanto aquém, como diferente do noema, que é o noema que normalmente se vê e ela só se vê na atitude da reflexão; ou seja, ele pensa exactamente a mediação da hylê, apesar das exigências do sistema, à maneira da tradicional representação de género quo. O que, justamente, e é isso o que aqui nos importa, não é possível. Porque o meio ou é transparente e não é meio, ou é algo que se vê, mas nessa exacta medida não se vê a coisa, e não é igualmente meio. Não é possível a mediação.

O que acontece é que, supondo-se em nós um duplo das coisas para explicar a memória, se julga desde então, mas vagamente, que o conhecimento se faz através desse duplo; quando, como é o caso de Aristóteles e depois da sua tradição, se põe minimamente o problema, diz-se que «se vai na imagem» e é tudo. Vaguidade que, aliás, não acontece só a respeito da mediação, mas também a respeito da sua natureza. Quando Aristóteles põe este último problema, ele diz na verdade que «não é a pedra que está na alma, mas a sua forma» ${ }^{31}$. Contudo, o que quer isto dizer? Que a pedra da alma perdeu a matéria? Aceitemo-lo. Mas não tem, para ser a imagem da pedra, a efectiva cor cinzenta, o seu frio próprio e a sua rijeza? $\mathrm{Ou}$ - já que se tem isto é uma efectiva pedra que pode bater noutra - nem estas qualidades tem? Mas então o que é a imagem da

30 Ideen-I, § 97.

${ }^{31}$ De an. III, 8, 431 b 29. 
pedra? A resposta é: as palavras que a referem a vazio. Nomeando-a, ela lá está e na perfeição das suas qualidades. Contudo ainda a vazio, ao nível das puras palavras, e portanto não há lá pedra nenhuma. É isto a pedra na alma, é isto o duplo. E por isso, sempre que nos colocamos do ponto de vista da sua necessidade, para explicarmos primeiro a memória e depois a percepção, ele lá está; de resto, com a evidencia que resulta dessa necessidade: pois que, se se pensa que ele é necessário para a memória e para a percepção, e temos estas, ele em absoluto está lá: a sua evidência é a desta implicação, não a da sua intuição, que nunca existe. Mas está lá, é o ponto, só como pode estar, a vazio, ou como diz Aristóteles, sem a matéria, porque a pedra mesma só existe lá fora e não na alma. O que significa que não há, afinal, para além da impossível mediação, também nenhum duplo das coisas em nós, mas apenas estas, lá onde elas se dão. - Lá, não só no espaço mas também no tempo: porque a memória é, tal como sucede na percepção, ver as coisas lá no seu presente anterior, só que, e é essa a sua diferença em relação à percepção, através do nada que a seguir a esse presente elas são até hoje; mesmo na memória imediata, já há o nada que a coisa agora é, e que justamente já a faz ausente, nada e ausência que não existem na percepção. Pelo que não há, nem na memória, nenhum duplo.

\section{O acto comum como problema}

E eis-nos, depois de destruída a representação, de regresso ao acto comum. $\mathrm{O}$ grande problema do conhecimento foi sem dúvida, historicamente, o dessa representação. Antes de Descartes, é sobretudo ele que já aparece nos eflúvios (aporroaî) de Empédocles ${ }^{32}$, nas imagens (eídôla) dos Atomistas $^{33}$, nos critérios de verdade dos Estóicos e dos Epicuristas, na tradição céptica, e mesmo no próprio acto comum de Aristóteles, porquanto ele se processa no sujeito e não no objecto exterior ${ }^{34}$ : este último actualiza a potência que a alma é de todas as coisas ${ }^{35}$ e é através do duplo assim produzido que o sujeito vê o objecto lá fora. E depois de Descartes, vimos como a representação de género quod nos fechou tanto aquém das coisas que, mesmo antes da questão do acesso, o problema era o de saber se elas existiam. Mas nem por isso, como igualmente vimos,

${ }^{32}$ G. S. KIRK, J. E. RAVEN e M. SCHOFIELD, Os Filósofos Pré-Socráticos, trad. De C. A. L. FONSECA, Fundação Calouste Gulbenkian, Lisboa, 1994 (University Press, Cambridge, 1983), pp. 323-326.

33 Ibid. pp. 452-454.

${ }^{34}$ De an. III, 2, 426 a 9-11.

35 Ibid. 8, 431 b 21 e 26-27. 
o acto comum deixou de estar presente, como o verdadeiro, e por isso o essencial, problema do conhecimento. Justamente Hegel faz o sujeito produzir o objecto, para que ele possa ser conhecido, e Heidegger converte a «essência» do homem numa pura «ek-sistência», com o mesmo objectivo $^{36}$. O que significa, contra o que pode parecer imediatamente, que quando Hegel ou Heidegger terminam é que é preciso começar. Porque evidentemente não basta dizer que o sujeito produz as coisas, ou que o homem se reduz a uma abertura no meio delas. Falta tudo para saber se há conhecimento ou não. Porque, digamo-lo ainda uma vez, conhecer é juntar a consciência às coisas por conscienciar, dando como resultado as coisas conscienciadas. $\mathrm{O}$ que vem a ser esta consciência enquanto tal? E o que vêm a ser as coisas enquanto ainda não conscienciadas, e portanto sem delas podermos falar? Evidentemente não podemos ter a pretensão de nestes breves momentos expor o problema de um modo minimamente satisfatório. Mas podemos pelo menos indicar o sentido das análises, apontando os resultados.

\section{Resultados da análise do acto comum}

Antes de mais, não é o sujeito que é primeiro mas o objecto: é porque se supõe que há objectos por conhecer que é preciso uma consciência que os conheça; ou, o que é o mesmo mas negativamente, nunca se pensaria nessa consciência, se as coisas já aí estivessem sempre patentes. E, sendo assim, o verdadeiro problema é o do objecto. Contudo, não deixemos de notar que já esta simples funcionalidade da consciência a anula. É que, sendo ela função do objecto, sendo ela para termos o objecto, se ela fosse alguma coisa, isso mesmo nessa medida nos separaria dele, e ela não cumpriria a sua função. Dir-se-á que a consciência é uma simples luz que ilumina o objecto e assim o tem; que sem essa luz é que não o podemos ter de modo nenhum. Responderei que é preciso levar a sério essa luz de que falamos; se ela, para além de servir para termos o objecto, é mesmo uma luz, ela é algo de que podemos tomar consciência, é objecto, e não mais a consciência que procuramos. Não há volta a dar-lhe: a consciência ou é logo o nada, dada a sua função, ou, se é alguma coisa, seja o que for, é antes $o$ que é visto, é um objecto, não o ver, a consciência que se queria para o ter.

36 «A essência do Dasein está na sua existência»: M. HEIDEGGER, Sein und Zeit, Max Niemeyer, Tübingen, 1927, p. 42. Ver particularmente o $\S 43$, que resume a sua posição. 
Mas deixemos pois o sujeito e passemos ao objecto, porque é ele que constitui o verdadeiro problema. Dado que não há mais representação alguma, mesmo a de género quo, a única transcendência que resta é a temporal: a do tempo em que as coisas existem mas não são percebidas nem pensadas ${ }^{37}$, porque estamos ocupados a perceber ou a pensar outras. Esta transcendência, sim, é verdadeira, porque há uma multidão de coisas ao mesmo tempo, e nós só podemos ver uma de cada vez: enquanto a vemos, as outras ficam-nos necessariamente de fora, são-nos transcendentes. É verdadeira, e foi ela que, no contexto de não haver ainda a descoberta do ver como condição do ser, deu origem ao conhecimento. É que, existindo as coisas, mas não para nós, existindo, mas não percebidas nem pensadas (e justamente não se sabendo que elas só existem, e dessa maneira, porque são pensadas de um outro ponto do tempo), é preciso que tomemos consciência delas, para que sejam para nós. Se considerarmos, por um lado, o prazer e a dor e, por outro, por exemplo um relâmpago, compreenderemos em concreto do que se trata. O prazer e a dor nunca são objectos no sentido que aqui nos importa, porque nunca os há sem deles termos consciência; enquanto o relâmpago, embora sendo instantâneo e luminoso e por isso não nos passando habitualmente despercebido, já é um objecto de que tomamos consciência; isto é assim porque eu sei pela experiência - através nomeadamente dos que mal vejo - que há todos aqueles que existem mas que eu, ocupado a ver outras coisas, não vejo; quando vejo um, já tomo consciência dele,

37 Já basta decerto que não sejam percebidas: podemos estar a pensá-las (como existindo lá contemporaneamente) e passar desse pensamento à percepção; como acontece por exemplo quando, estando à espera do autocarro, o pensamos como estando já na parte anterior da curva e de facto ele aparece logo. Não o tendo então em pessoa, enquanto simplesmente o prevemos, mas naturalmente referindo-nos ao autocarro real ou em pessoa, já há esta diferença que vai do pensado (ou, o que é o mesmo, do imaginado) à percepção, já há a parte a-vazio do pensamento. Por tal diferença - enquanto visamos o que não temos - o autocarro já nos transcende e, como diremos a seguir, julgando nós que se trata de uma transcendência absoluta e não só relativa, já precisa da consciência, para ser para nós. - Contudo, já só nos referiremos ao caso em que as coisas não se percebem nem se pensam durante o tempo que está em consideração, por três razões. Em primeiro lugar, para simplificar. Depois, para tornar a questão mais evidente, uma vez que, nem sequer pensando o objecto, teremos então toda a diferença que vai do zero à plenitude das respectivas determinações. Enfim porque esta passagem da previsão à percepção não é o caso mais comum mas uma excepção: basta que o autocarro demore uma pouco mais para que eu me distraia, e já não o pensava quando ele afinal apareceu. Aliás, havia todo o tempo anterior à previsão, em que o autocarro existia e não era percebido nem pensado, porque estávamos ocupados com outras coisas. É inevitável. Na imensa maior parte da duração das coisas, estas existem, sem serem percebidas nem pensadas. 
porque eles são, através deste tempo em que não são vistos, algo que existe sem ela. A transcendência temporal, para além pois de ser um facto, foi bem a origem do conhecimento. É claro, repitamo-lo, no contexto da não-descoberta ainda do papel do ver. Porque, se em verdade ela só é possível enquanto pensada de um outro ponto do tempo, ela é afinal só relativa e não absoluta; isto é, dá-se já sempre na imanência do pensamento, e não fora, com a neste último caso necessária tomada de consciência. Contudo esta imanência é exactamente o que não se tem visto e, por consequência, é o que é preciso pôr em relevo.

Para esse efeito, tomemos um exemplo, que pode ser o habitual nas aulas e que vem de Nova Filosofia ${ }^{38}$. Seja esta mesa que vejo (percepção portanto) durante, digamos, 2 segundos; depois saio a ver outras coisas e a conversar com os amigos, durante, suponhamos, 30 minutos; regresso, percebo de novo a mesa durante 2 segundos, e logo a seguir penso, durante 2 segundos, que a mesa esteve cá durante os 30 minutos. Note-se que o problema não é o de saber se a mesa cá esteve mesmo enquanto fui ver outras coisas e conversar; isso é sem dúvida um problema depois de Hume, mas aqui partiremos já da posição tradicional de que as coisas permanecem no intervalo das percepções. Pelo que o problema é o de saber se elas, existindo durante esse tempo, existem em absoluto sem o pensamento. Ora é um dado do exemplo que, ocupados a ver as outras coisas e a conversar, nós de facto não pensámos contemporaneamente a mesa em nenhum momento desses 30 minutos. Pois sim, mas pensámo-la não-contemporaneamente. É no terceiro acto de consciência, logo a seguir à segunda percepção, que nós pensamos que a mesa cá esteve durante os 30 minutos. Se não houvesse este terceiro acto de consciência, pura e simplesmente não haveria a mesa no intervalo das percepções. Dirão que podemos eliminar o terceiro acto de consciência e ela lá continua na mesma no dito intervalo; que ela é uma coisa em si ou independente de ser pensada. Bom, que ela é uma coisa em si, ou independente, é o que se costuma afirmar e já começámos mesmo a compreender porquê; contudo o que aqui está em jogo é averiguar se o é; se ela for verdadeiramente independente, resistirá à prova. Ora o que sucede é que, ao dizerem que se eliminarmos o terceiro acto de consciência ela lá continua, a estão então, nesse preciso momento, a pensar lá: ao dizerem que «lá continua». Aquele terceiro acto de consciência - notemo-lo bem - situa-se no exemplo logo a seguir à segunda percepção, mas é óbvio que se pode situar em qualquer outro

${ }^{38}$ pp. $10-11$. 
ponto do tempo, à excepção do tempo das percepções ${ }^{39}$. O importante é tomarmos consciência de que, sem pelo menos um momento de pensamento que pense a mesa no intervalo, ela pura e simplesmente não existe. Não é decerto fácil fazer esta experiência, porque, mesmo quando dizemos que não (a) pensamos, a estamos justamente a pensar. Por isso, para a não pensar mesmo, procedamos desta forma: tapemos o pensamento, desliguemo-lo como quem desliga um interruptor. Então, sim, apercebemonos de que tudo desaparece (mesmo isto a que ainda se alude ao dizer tudo).

É completamente claro: se fazemos a experiência, os objectos para conhecer - porque julgados em absoluto transcendentes - têm afinal de ser referidos, e referidos pelas determinações das percepções, já que não há outras. Se por exemplo partimos da percepção para o tempo anterior do respectivo objecto, este é já explicitamente essas determinações, só que, porque pensadas no tempo em que não foram percebidas nem pensadas, como nada para nós: por baixo do efectivo nada que lá houve para nós, houve essas determinações que lá pensamos agora. Se, em contrapartida, imaginando-nos nós nesse nada, quiséssemos pensar já o referido objecto (portanto a montante da percepção), poderíamos ainda fazê-lo, só que inteiramente a vazio, como na realidade podemos hoje pensar inteiramente a vazio o que nem imaginamos que vai aparecer daqui a mil anos: pensamos exactamente essas determinações da futura percepção - não é outra coisa o que pensamos -, só que inteiramente a vazio. Ou seja: nunca há o objecto para conhecer, porque ele já é sempre conhecido; tudo o que há é a passagem do a-vazio (com os seus diferentes graus) ao a-cheio.

Se, ao longo da história, se pensou o contrário, foi porque sempre se ignorou que as coisas só existem nesse tempo em que não são percebidas nem pensadas porque nós, de um ponto qualquer do tempo, as pensamos lá dessa maneira; e isto por sua vez aconteceu por não se ter ainda descoberto o ver como a condição do ser. Tal descoberta, como o

39 À excepção do tempo das percepções, porque então estamos, sem mais, a perceber as respectivas coisas. Mas é perfeitamente possível partir de uma percepção e referi-la como sendo o que existe no respectivo intervalo: por exemplo, partir da segunda percepção da mesa e dizer que é isso mesmo que continuamos a ver (não portanto já memória, mesmo que imediata, como o supomos no exemplo) que está nos 30 minutos. Contudo, precisemo-lo, este encher o intervalo com o «em pessoa» da percepção não transforma os 30 minutos em percepção. Porque é o «em pessoa» da percepção posto num tempo em que não houve percepção. Para já não falar em que não vou estar 30 minutos a pensar esse «em pessoa» dos 30 minutos originais. Ou seja, para além de lá não ter havido percepção, há ainda sempre o a vazio que resulta de, em segundos, nos referirmos a 30 minutos. Pelas duas razıes, mesmo utilizando a percepção para referir o que houve num tempo passado, o que temos é uma imaginação, não a percepção. 
dissemos, só sucedeu com Descartes. Contudo, as conversões culturais, quando são profundas, levam sempre muito tempo a completar-se. Mesmo em Hume ou Husserl não há ainda o terceiro acto de consciência do exemplo, não há este pensamento que pensa as coisas no tempo em que elas não são percebidas nem pensadas. $O$ primeiro, decerto, já fala na «imaginação» que, mais poderosa que a «razão», constitui a continuidade das coisas para além das percepções. Mas não se trata ainda, de modo nenhum, de um verdadeiro acto de imaginação, com o seu tempo próprio e, sobretudo, com a dependência do objecto em relação a ela, antes, como ele também diz, de uma «natureza», de um «instinto», de um «senso comum», ou seja, ao fim e ao cabo trata-se de invocar o inveterado hábito do ser como independente de ser conhecido. E Husserl, ao partir sistematicamente das vivências para o objecto, fica condenado à partida a perder mesmo a transcendência temporal: primeiro porque já tem o objecto ao nível da unidade transcendente das vivências, e depois porque, se não se pode de todo evitar a transcendência temporal, ela só pode ser, neste contexto, função de vivências possíveis, não justamente algo que por definição não pode ter vivência alguma e que por isso mesmo não pode à partida ser constituído por elas; ora, tendo-a assim perdido à partida, ela não podia evidentemente ser descoberta e reduzida. Foi talvez esta exacta transcendência temporal que mais faltou ao seu imenso esforço para chegar às «coisas mesmas». Na verdade, se se parte dela e da consequente redução, há os momentos plenos, que são as percepções, e há os momentos em que, em poucos segundos, se pensa o tempo - horas, anos, milénios - que as coisas duram sem ser percebidas nem pensadas. Hoje em dia, por exemplo, graças à percepção do afastamento das galáxias, pensamos que o universo tem cerca de 15 biliões de anos. Esse tempo é agora que existe, quando o pensamos e pelas razões que o pensamos ${ }^{40}$. O tempo é agora verdadeiramente o dos actos de consciência,

${ }^{40}$ Mas estamos a referir-nos, notemo-lo bem, ao universo físico. Se supusermos que o homem tem, digamos, 2 milhões de anos (e abstraindo ainda dos animais), já há também desde então o tempo absoluto das percepções e dos actos de pensamento de cada um. O tempo é doravante, como dizemos já a seguir, psicológico e não cosmológico. Com efeito, o real absoluto é o das percepções e o dos actos de pensamento de cada sujeito que existir (sendo o relativo o a-vazio enquanto tal, referido pelo pensamento). De cada sujeito que existir, digo, porque, não havendo mais o real independente dos sujeitos, que simplesmente o conscienciariam, há tantos mundos quantas as consciências. Mundos que decerto supomos qualitativamente idênticos ou pelo menos muito semelhantes, mas que nem por isso são menos numericamente distintos: justamente pensar os outros como as consciências que são é pensá-los como algo em si, quero dizer, como algo a que por definição não podemos ir porque não se vai de uma consciência a outra, é pensá-los como 
não o cosmológico que sempre tem sido, de Sto. Agostinho a Kant, a Husserl e a Heidegger. Se, como o experimentámos, quando tapamos o pensamento, quando o desligamos, tudo desaparece, as coisas, durante o tempo em que não são percebidas nem pensadas, só existem porque nós, neste ou naquele momento, as pensamos lá. Aliás - e concluímos Heidegger já o diz. No fim do $\$ 43$ de Ser e Tempo, ao reconhecer que, faltando o Dasein, nada se pode dizer das coisas - não se pode dizer «nem que são nem que não são»-, mas que nem por isso elas desaparecem, conclui que é agora, quando o Dasein existe, que se pode dizer que, quando ele não existe, elas lá continuam; ou seja, que é a partir da nossa existência actual que se pode falar nomeadamente no universo anterior ao homem. Só que, evidentemente, Heidegger também não viu o referido terceiro acto de consciência. E por isso o que agora pensamos é tido mesmo por transcendente e desconhecido. A precisar do Dasein como abertura no meio das coisas ou, na sua linguagem grega, como a-lêtheia.

inteiramente para além de nós. Assim, quando pensamos os 15 biliões de anos do universo, ao chegarmos aos 2 últimos milhões, há também, justamente para além desses pensamentos de nós sujeitos de hoje, essas percepções e esses pensamentos dos homens que lá pensamos. - Se quisermos dizer tudo, nós hoje pensamos os biliões do universo, que incluem naturalmente os da Terra anteriormente ao aparecimento da vida. Depois pensamos o primeiro animal, isto é, pensamos que para além de um determinado corpo já há um mundo seu paralelo ao nosso, só que reduzidíssimo. E assim sucessivamente os peixes, os macacos, os primeiros homens, com os seus mundos progressivamente maiores. Tal como hoje pensamos - tal como cada um de nós hoje pensa - os outros homens, com os seus mundos à imagem e semelhança do nosso. 